\title{
JOSEPH SCHACHT
}

Joseph Schacht was born in Ratibor, formerly in Upper Silesia, now in Poland, on 15 March 1902 and attended the Gymnasium in that town. It was there that he acquired his first interest in oriental languages. During the period set aside for religious studies, a rabbi came to teach the Jewish boys Hebrew. Although the young Schacht was not one of them, he managed to complete his other tasks and to get himself accepted in this group, where he took his first steps in Hebrew. Later he studied classical and then oriental philology at the Universities of Breslau and Leipzig. In 1925 he received his first academic appointment at the University of Freiburg im Breisgau; two years later he was appointed Associate Professor, and in 1929 was appointed full Professor of Oriental Languages at the unprecedented age of 27. In 1932 he was invited to a chair in the same subject at the University of Königsberg, but his effective tenure of that chair was very brief because of political changes in Germany. Though not exposed to danger on either racial or political grounds, he elected, as a matter of conscience, to leave Germany when the Nazis came to power. Between 1926 and 1933 Schacht had travelled extensively in the Middle East and in North Africa, and in 1930 had served as a visiting professor at what was then known as the Egyptian University in Cairo. When he left Königsberg in 1934 ' on leave of absence', it was to Cairo that he returned ; he stayed there as Professor until 1939.

After the outbreak of war he moved to England where he worked for the BBC and British Ministry of Information throughout the war years. He was naturalized as a British subject in 1947.

In 1946 he was appointed to a teaching post at the University of Oxford, with the rank of lecturer; he was appointed Reader in Islamic studies in 1948. During his years at Oxford he made a number of trips abroad a lecture tour in the United States in 1948, a research mission to Nigeria in 1950, a visiting professorship at the University of Algiers in 1952, and a research mission in the Near East and East Africa in 1953.

In 1954 he left England for Holland, to take up the chair of Arabic at the University of Leiden-for long regarded as among the most distinguished in this field. His stay in Holland was, however, of brief duration. In the academic year 1957-8 he went as visiting professor to Columbia University and returned there in 1959 to a regular appointment as Professor of Arabic and Islamics. He remained there until his retirement in 1969. He undertook further research missions in East Africa in 1963 and 1964, and was a Guggenheim Fellow in 1967. He died at Englewood, New Jersey, on 1 August 1969.

The first field of study to which Schacht gave his attention was that of Islamic law ; it remained one of his principal concerns to the end of his days. In contrast to most other scholars in the field, Schacht's approach was neither theological nor juristic, but rather historical and sociological. That is to say, he was concerned with the Holy Law of Islam, not so much as an ideal or as a theoretical system, but as it evolved and was actually administered in the 


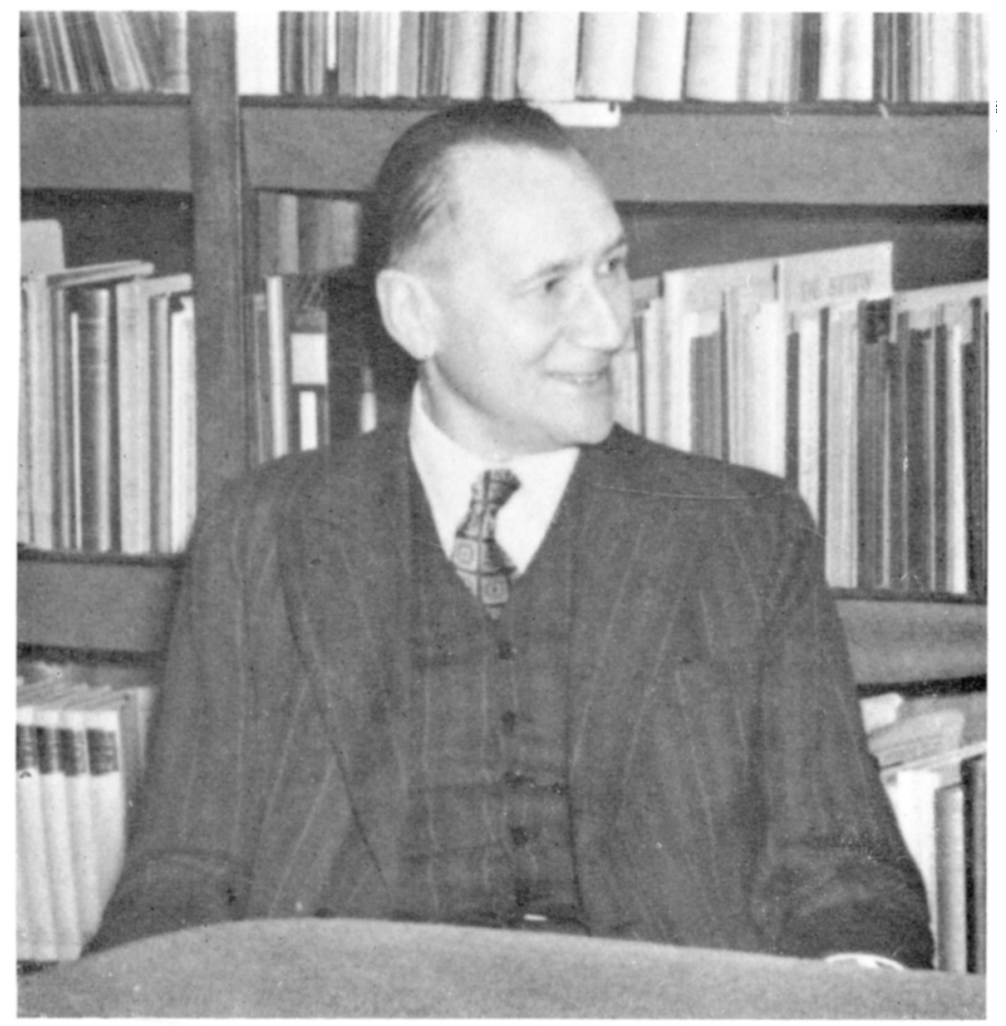

JosEPH SCHACHT

BSOAS. XXXIII] 
Islamic lands. His first subject of research was the important and neglected topic of the hiyal, the legal devices or stratagems by which transactions outside the scope of -or even contrary to-the Shari $\bar{\imath}^{-} a$ could be protected and adjudicated under the Shari $i$, through the use of legal means for extra-legal ends. In 1923 and 1924 Sehacht published editions of two of the most important Arabic texts dealing with this subject, and in 1926 published his epoch-making article, 'Die arabische hijal-Literatur', in Der Islam, xv. The subject was further developed in his later writings, and has become a commonplace in all serious subsequent work on the history of Islamic law. Since the device of hiyal was extensively used in commercial matters, his discoveries in this field are also an important contribution to the study of the social and economic history of Islam.

The same interest in the realities of Muslim law led him, after his first stay in Egypt, to examine an important problem hitherto virtually unknown to Western scholarship-that of the application of Sharī $a$ law in modern Islamic states. The phenomenon of Islamic legal modernism was analysed in detail, against both the historical and systematic backgrounds, in his pioneer article ' Šarī' $a$ und Qūnūn im modernen Ägypten ' in Der Islam, xx, 1932. A shortened version, brought up to date, appeared in French in 1949. This study formed the basis of a whole subsequent literature dealing with this important topic. Another question, on which he produced important pioneer work, was that of foreign influences on Muslim law. Touched on in some of his early articles, this topic was examined in greater detail in his study "Foreign elements in ancient Islamic law' (Journal of Comparative Legislation, Third Series, xxxII, 1950 ; reprinted with additions in Mémoires de l'Académie Internationale de Droit Comparé (Rome), III, 4, 1955) and in his paper 'Droit byzantin et droit musulman', in XII Convegno Volta, Rome, 1957, 197-230.

The sociological study of Islamic law, in more general and theoretical terms, was initiated by his paper 'Zur soziologischen Betrachtung des islamischen Rechts' (Der Islam, xxII, 1935), and pursued in other articles.

In the meantime Schacht continued his studies on the origins of Muslim law during the early centuries. A number of articles showed the direction of his researches, notably his 'Revaluation of Islamic traditions', published in the $J R A S$ in 1949. These were crowned with the publication of his classic work The origins of Muhammadan jurisprudence, Oxford, 1950. Several subsequent editions appeared, the latest being the fourth, published in 1967. In this book Schacht, continuing the work of his great predecessors Goldziher and Snouck Hurgronje, subjected the whole of the early juristic and traditionist literature to a minute critical examination. Essentially, Schacht's work in this field falls into two parts. The first was to recover and reinterpret the researches of Ignaz Goldziher. Goldziher's profound and brilliant studies on hadith had shown for the first time that these 'traditions' about Muhammad and his Companions reflected the conditions, not of the period to which they were ascribed, but of that in which they were produced-i.e. that they expressed, 
and were devised to support, opinions current in various circles during the first two and a half centuries after the death of the Prophet. Despite lip-service to Goldziher's genius, his findings were often neglected, and the study of early Islamic law and history was pursued as if the older view which he had demolished was still valid. In Schacht's phrase, 'arbitrary guesswork, sometimes called historical intuition, began to take the place of sound historical criticism ', and the originality and authenticity of the great body of traditional material were tacitly or even explicitly accepted. With the exception of a neglected work published by D. S. Margoliouth in 1914, Schacht was the first to resume the critical study of the tradition and especially of the $i s n \bar{a} d$, to pursue it in a still more radical form, and to demonstrate the implications of this critique, primarily for legal and theological, but also for historical evidence, much of which is, as he showed, legal in origin and purpose. Having continued the work of Goldziher, Schacht then proceeded to do what Goldziher had hardly attempted-to erect a new structure in place of that which had been demolished. By his studies of early legal literature, and particularly of the polemics of Shäfici against his predecessors, he 'dismantled two layers of fictitious information which disfigure, while they reveal to the discerning eye, the early history of Islamic law', and then went on to show how, in the generation of the so-called 'Successors', the real historical development of Islamic law could at last be perceived; how, towards the end of the first century of the Islamic era, the first religious specialists began the process by which they and their followers imposed a religious and ethical pattern on a mass of disparate legal precedents, practices, and rulings, and transformed them into the system of Islamic law. His findings have revolutionized our understanding of the early history of Muslim law and with it of Muslim theology, literature, and indeed of Muslim society. A brief but comprehensive survey, including the results of his own researches on both early and later Muslim law, was given in his lectures at the University of Algiers, first published in French translation as Esquisse d'une histoire du droit musulman, Paris, 1953. An expanded version appeared in English in his Introduction to Islamic law, Oxford, 1964, second edition 1966.

Apart from law, Schacht's interests ranged over the whole field of Islamic scholarship. Besides studies and editions of Arabic manuscripts, he published articles dealing with subjects as diverse as Islam in West and East Africa, the history of the minbar, the Ibādīs of Mzab in North Africa, as well as numerous other topics in the field of Islamic theology. His last book was an edition with an introduction, translation and notes, prepared jointly with the late Max Meyerhof, of the work known as the Theologus autodidactus of Ibn al-Nafis. A new version of the Legacy of Islam, which he had edited and in part written, is in the press and should appear shortly.

In addition to his own work as a scholar and as a teacher, Schacht made an important contribution to the general development of his subject. He was co-founder and editor of the review Studia Islamica, with Professor Robert Brunschvig of Paris; he was also one of the editors of the new edition of the 
Encyclopaedia of Islam, publication of which began in 1954. Its harmonious progress during the last 13 years has owed very much to his leadership, his scholarship, and his devotion. He was awarded an honorary doctorate by the University of Algiers (1953), and elected a member of the Arab Academy in Damascus (1954) and the Royal Netherlands Academy (1956). In May 1969 he was awarded the Giorgio Levi Della Vida medal for Islamic studies by the University of California, Los Angeles.

It is characteristic of the man that, amid a busy life, he should have found time to publish two works of piety towards his predecessors. One of these was his carefully prepared and documented edition, from the author's rough and unfinished manuscript, of his teacher G. Bergsträsser's posthumous work Grundzüge des islamischen Rechtes, Leipzig, 1935. The other was the selection of writings by Snouck Hurgronje, which he translated and edited, jointly with G.-H. Bousquet, in 1957.

Schacht was a truly great scholar, one of the last in the great tradition of European orientalism. He was a man of immense learning and of meticulous philological accuracy, but at the same time his work possessed those qualities of profundity, of originality, of controlled imagination which alone can raise scholarship from the level of antiquarianism to that of creative achievement. A philologist of the classical type by training and temperament, he was nevertheless in touch with modern trends of social thought. His studies for example on the sociology of Muslim law show an easy familiarity with modern sociological concepts and methods, and must rank among the most important work of our time in the application of social science techniques to Islam.

In his personal life as in his scholarly work, Schacht was a man of complete and uncompromising integrity. It was for moral reasons that he left Germany when the Nazis came to power, and never again returned to his native land or wrote in his mother-tongue. He imposed the highest standards on himself and also expected them of others. The devil has many temptations. Those which he puts before the scholar in particular are to claim, or not to disclaim, knowledge which he does not possess, and to praise, or not to condemn, work which he knows to be shoddy - be it through politeness, interest, irenicism, or mere indifference. Schacht did not succumb to either of these, but was both humble and severe in matters of scholarship. Honest in all things, he was incapable even of the small social hypocrisies that academic and personal life so often demand. Perhaps for this reason he sometimes had the reputation of being a difficult person to get on with-one who might both give and take offence where none was intended. For those who were fortunate enough to gain his respect or friendship, this was not so. His friendship once given was complete and permanent. Behind the sometimes rather stiff exterior, there was a man of great kindness, loyalty, and humour. In Arabic and Islamic studies, his death leaves a void which cannot and probably never will be filled. As a colleague, a friend, and a man, he will be deeply mourned by those who knew him well.

BERNARD LEWIS 